\title{
What Supports Females In Higher Education Progression? A Pakistani Public University Context
}

\author{
M. Amin \\ Department of Education \\ University of Education \\ Muhammad Islam \\ Department of Education IER \\ University of Punjab \\ Humera Amin \\ Department of Education \\ University of Education
}

\begin{abstract}
The paper is focused on exploring the factors that support females' progression in higher education. The mixed methods approach is taken to conduct the research, consequently the study falls in pragmatic paradigm. The structured questionnaire is used to collect quantitative data from 201 M.Phil/Master level university female students, and semi-structured interview protocol is used to generate qualitative data from 15 female students of the same university. However, quantitative results are based on 191 useable responses. Descriptive statistics (frequency and percentage) has been used to analyse quantitative data, whereas content analysis has been used to analyse qualitative data. The data highlight that literate parents, global trend of females' acquisition of higher education, media, availability of jobs and scholarships are supportive factors in females' progression in higher education. An interesting finding revealed from the data is that 'Islamic Perspective' of education is also considered as encouraging factor; generally in Pakistani societal context, especially in remote areas, people use 'Islamic Perspective' in a distorted way to restrict their girls from getting higher education.
\end{abstract}

Keywords: Females’ Progression, Higher Education, Public University Context.

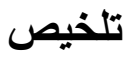

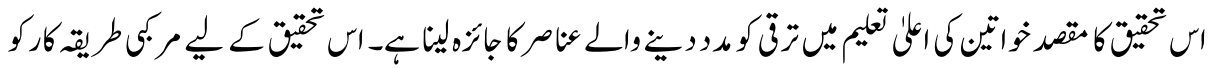

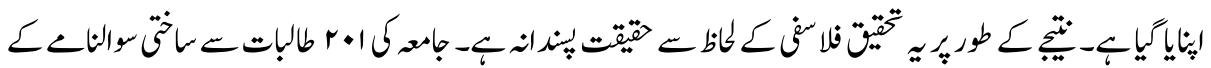

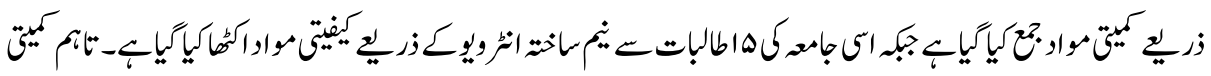

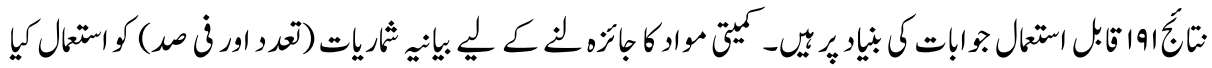




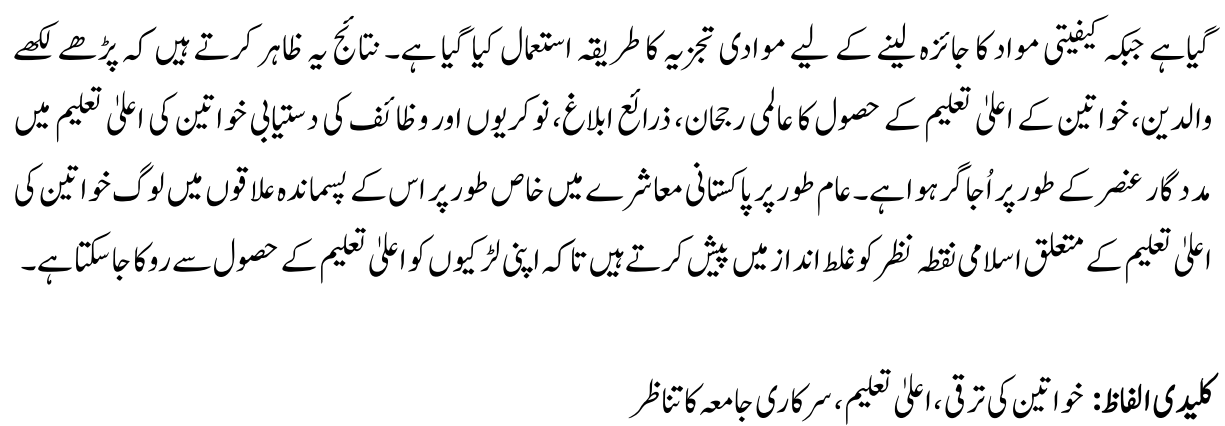

\section{Introduction}

Women make around half of the world's population, and their literacy rate is less than men. Females remained away from higher education because of various reasons in different parts of the world. Higher education plays critical role in the economic development of any country, however females' contribution in the world's economy is significantly less than men (Suresha \& Mylarappa, 2012). The world is paying high cost of it and the cost of keeping the women away from education in general and from higher education specifically is higher than the cost of equipping them with education (Aftab, 1995). In contrast to the developed nations where equal importance is being given to male and female education, females' higher education is one of the least attention receiving sector in developing countries including Pakistan (Mehmood, Chong \& Hussain, 2018). According to UNESCO institute of statistics by 2014 out of total 56.98 literate population of 15 years and older in Pakistan, 69.07 are male and 44.28 are female (UNESCO, 2019). This literacy rate was reported $58 \%$ by Education Minister Shafqat Mahmood in his speech in Senate reported in Dawn newspaper on $21^{\text {st }}$ December (Literacy Rate, 2018).

Amin, Tatlah \& Afghani (2018) investigated the barriers in women's progression in higher education and highlighted that ignorant parents, cultural norms, low socioeconomic status, unavailability of universities in remote areas, and stereotype thinking of families are some major factors. Another recent study by Mehmood, et al. (2018) focused on Pakistani context highlighted various factors affecting female higher education including physical security and threat of sexual harassment, lack of higher educational institutions on appropriate distance, Conservative and outdated local cultural norms and values, feudalism and its sub forms jagirdaari and zamindari system, poverty and deprivation, misconception of Islam, coeducation, and early marriages. There are many other studies that highlight the barriers in females' progression in higher education (Ali, Jumani \& Ejaz, 2015; Maqsood, Maqsood \& Raza, 2012; Naeem \& Dahar, 2016; Shaukat \& William Pell, 2015). 
Despite all these barriers it is interesting to know world's gender inequality is getting lesser with regards to females' education (UNESCO, 2012). A study conducted in a public university of Punjab point out that "number of female students in higher education is increasing in Pakistan" (Kaleem \& Rathore, 2017:37). Authors of this study also support this evidence based on their observation since researchers are working as faculty members at university level since 2012. However, it cannot be generalized Pakistan wide because above mentioned study is based on the 4 years enrolment data of one university and researchers' observation is also limited to few departments of two public universities. Yet, the researchers could not find a study focusing on what supports/facilitates females' progression in higher education in Pakistani context.

So, this study bridges this research gap and focuses on exploring the factors that support females' progression in higher education. Data shall be taken from female students of the university to unveil factors that are supportive in their progression in higher education. This research focuses to examine the issue from a different angle that is not usually taken by researchers to address the same problem. The study will explore factors that are supportive in females' progression in higher education and then it will suggest that how these factors can further be enhanced to address the issue under study. This study would be useful through providing some implications for parents/society and policy makers to improve females participation and success in higher education in Pakistan.

\section{Review of Literature}

Change and development in society affect differently to males and females. Efforts to develop women started back around 1970s and different approaches have been used and are being used for this purpose. However, education has been acknowledged as most effective tool to develop and make their role comparable to men in every aspect of life (David, 1993; Francis \& Skelton, 2001). Despite this admitted fact gap between men and women's education is not bridging at fast paced in general and in higher education specifically. For example in 2015-16 ratio of gross enrolment of higher education in Pakistan was $10 \%$, which was less than other countries in South Asian region; and ratio of females' enrolment in higher education increased from $36.8 \%$ in 2001 to $47 \%$ by 2014 (Ministry of Federal Education and Professional Training (MFEPT), 2017). This too slow pace is because of various reasons including govt. Priorities and budget allocation that can be observed from the fact that around $43 \%$ of the demanded amount for Higher Education Commission was cut down in 2019-20 budget (Banuri, 2019).

Education in general and higher education specifically develops females intellectually, makes them able to think logically and critically, enables them to run their home and groom their next generation more effectively, and helps them to develop their identity in the even male dominated society such as of Pakistan. Through nurturing their 
skill/knowledge/competency they become capable to enter and thrive in various professions/businesses. This in turn contribute in the country's economy along with making them empowered that helps them to prevent from various kinds of violence/exploitation (Sperling, 2004). Overall, higher education makes women's life comparatively easier, improves their living standard, and makes them less vulnerable to various cultural, economic, societal and professional disparities (Amin, et al., 2018).

These inequalities may be because of various reasons for example social norms of patriarchal and conservative society such as of Pakistan consider women's role to take care of their children and homes. Such societies consider decision making and leading role is the job of men instead women and females are supposed to follow, therefore higher education is not the women's need (Colclough, Rose \& Tembon, 2000). The classic example of male dominancy in Pakistani culture can be seen in the females' names, before marriage female have their father's name as their surname and after marriage they have their husband's name as their surname. Such stereotype thinking is one of the reason and symbol of male dominancy. Family as unit is always headed by male usually oldest who takes decision even about females' education and marriage. This is one reason that keeps females away from higher education. However, as mentioned in the introductory part, females have started to get higher education with good grades than their counterpart that made them able to work as professional (Kaleem \& Rathore, 2017).

Above debates highlight that females' education is inevitable for themselves, their families and nation, but at the same time female slag behind their counterpart in general/school education. This gap further widen sat higher/professional education level in Pakistan. There may be different angles to look at this issue. For example one way is to find out barriers that women's are facing in higher education and then suggesting measures to remove these barriers. As mentioned in introductory part various studies (Amin, et al., 2018; Mehmood, et al., 2018; Naeem \& Dahar, 2016) focused this aspect. Another approach to research this issues is exploring the factors that are supportive to females' progression in higher education and then suggesting ways to enhance such factors, which is followed in this study. Some of such factors are discussed here including literate parents, global trend of females' higher education, women development and Islamic perspective.

\section{Literate Parents}

Literate parents as compared to illiterate parents are generally more inclined toward their daughters' higher education because of many reasons. Father's role in this regard is critical especially due to patriarchal structure of the Pakistani society (Mehmood, et al., 2018). Literate parents want their daughters to be well educated as it helps in finding better marriage matches, they become independent and able to spend better life after 
marriage. In case of any unfortunate incident such as husband's death, divorce, or if husband is not supporting as such because of his second marriage, highly educated females are more likely to spend their life with less problems as compared to illiterate females because in such cases educated women can do job. It has been observed in Pakistani society that if parents equip their daughters with higher education, they get jobs and even support their parents and family that improve their living standard (Afghani, 2015). Literate parents have understanding that educated females are less likely to be exploited as compared to uneducated. In other words it can be said that higher education lessens the obstacles that females face in male dominated society and makes them parallel to their counterpart in every aspect of life like in the advanced world (Sharma\& Sharma, 2004).

Literate parents also have the understanding that highly educated female not only improve their life economically, they also contribute in country's economy, help to decrease poverty, support in eradicating illiteracy through educating their children and consciously empower their daughters through higher education (Stephan, 2002). Literate parents also acknowledge that highly educated females are less likely to be exploited at home and workplace. In extreme cases such women use their legal rights to protect them for example using separation right in case of domestic exploitation because they know it. In conservative society of Pakistan it is almost out of question that an uneducated woman ask for separation even after experiencing extreme exploitation because it is considered against the cultural norms and values. However, Pakistani laws and Islamic laws allow it. This is what is alarming (Government of Pakistan, 2003).

\section{Global Trend of Females' Higher Education}

It is worldwide acknowledged fact that women are leaving men behind in higher education remarkably (Bilton, 2018). This trend is increasing every year in most of the countries in every region of the world for example UK, Panama, Sri Lanka and Jamaica. Malaysia has been noticed that around $65 \%$ of its university students are female and this accelerating trend has been observed over the years (Bilton, 2018). As mentioned in the introductory part this trend is also being observed in Pakistan (Afghani, 2015) but not at good pace. Traditionally this trend remained in men's favours (Osunde \& Omoruyi, 2003), the shift in trend was observed back in 1970s and by 1990s women took the lead. There may be different reasons behind it for example it is observed that boys are less focused as compared to girls in their school age, so they spend less time on their study resulting in lower grades that leads their low enrolment in universities. Another reason was pointed out that traditionally women choose skilled carriers such as teaching and nursing, initially these professions were not demanding full degrees. Later when it changed, there was a big shift in university enrolment from men to women (Richardson, 2016). 
In the context of Pakistan it is observed that women were getting less opportunities as compared to men to go to school and colleges. As people became aware with the importance of education and started to send their daughters in school/college, it is observed from the school and college results that girls outperform the boys. Therefore, with all barriers in way of women's higher education, females' school/college academic performance helped them to shift the traditional men dominated enrolment to women in universities. International institutions like UNO have consistently been emphasizing the importance of females' higher education and influenced the countries to take measures for it (UNESCO, 2008). Moreover globalization made the people closer around the world through technology and now the world is considered as a global village. This advancement increased the interdependence of people around the globe and provided employment and higher education opportunities. These are some other reasons of this international trend.

\section{Women's Development}

Around the world there is special focus on women development. In developed countries such as UK and USA this focus is seen in less intensive form because there women are already much empowered and independent. However in developing countries such as Pakistan and under developed countries like of Africa women development initiatives are more rigorous and visible. In Pakistan, in the light of $18^{\text {th }}$ constitutional amendment that was passed back in April 2010, provincial governments developed a special focus to deal the women issues in Pakistan.

Taking the Punjab province as example, where the Department of Women Development was established in April 2012 to ensure women's empowerment and to create enabling environment for the women both at job place and societal level. This department is aimed to provide women financial/technical support, social uplift, access to justice, protection against violence/exploitation, eliminating discriminatory behaviour/attitude toward women, improving social/political/economic status, and achieving gender equity/equality. This department is doing efforts to achieve all these through various initiatives such as scholarships for study, working women hostels, day care centres at work place, public sector employment through specific quota, interest free loans, vocational training centres and maternity leave to name some (Women Development Department, 2019). Moreover various NGOs are also working specifically for women's development. Media is also playing important role in this campaign. Further details on what Women Development Department is doing and how it is doing to achieve the women empowerment and their prevention from all kinds of discrimination/exploitation can be obtained from its website. 


\section{Islamic Perspective}

Islam as religion makes the girls' education mandatory instead forbidding. It is wrong interpretation that Islam restricts females from getting education. In fact some political and religious leaders of Pakistan and other countries misinterpret the Islamic perspective on women's education for their personal gains. Some cultural norms/values, patriarchal societal system, poor educational policies, and media added in this misinterpretation (Khattak, 2009). In fact Islam advocates and makes the females' education obligatory as is evident from below quoted versus of Holy Qura'an and Ahadith (plural of hadith saying or action of prophet Muhammad (peace be upon him (PBUH)):

"Acquisition of knowledge is binding on all Muslims" (Al-Sunan 1:81 - 224).

This hadith highlights that there is no discrimination in Islam regarding male and female education because Islam teaches equality and justice. Holy Qura'an was begin with these verses:

"Read. Read in the name of thy Lord who created; [He] created the human being from blood clot. Read in the name of the Lord who taught by the pen: [He] taught the human being what he did not know" (Quran, 96:1-5).

"Are those who have knowledge equal to those who do not have knowledge?" (Quran, 39:9).

These verses emphasize the importance of knowledge regardless of gender. There are many other sayings and actions of prophet Muhammad (PBUH) that make the acquisition of knowledge mandatory for both male and female:

"Seek knowledge, from the cradle to the grave."

"Acquire knowledge, even if you have to go to China for it."

"The person who goes forth in search of knowledge is striving hard in the way of Allah, until his/her return."

These Ahadith can be read in various Ahadith books and are quoted by many authors (Huda, 2019:1). Some other authors who studied Islamic perspective on women's education have also quoted various Ahadith and Quranic Verses to highlight the importance of education for both male and female(Onaid, 2014). Two wives of prophet Muhammad (PBUH) named as Khadijah Binte Khuwaylid and Aishah Binte Abu Bakr were highly educated. The evidence of their higher education can be seen from the fact that Khadijah Binte Khuwaylid was running her own business internationally and Aishah Binte Abu Bakr played a leading role to guide Muslims in many matters after the prophet 
Muhammad (PBUH) (Onaid, 2014; Armstrong, 2006). This also highlights that Islam never forbids females from higher education rather Islam makes their obligation to get education.

\section{Methodology}

The mixed methods approach has been adopted to carry out the study, therefore its philosophical paradigm is pragmatism. The population of the research comprised on 457Master and M.Phil level female students from three units of one campus of a Lahore based public university. M.Phil students were 31 and 426 were Master's students. All the 31M.Phil and 170 Master's students (201 in total) were taken in the sample with almost equal representation of all three units. Structured questionnaire was used to collect the quantitative data and all the 201 participants returned the questionnaire. However, 10

questionnaires were not useable, they were either incomplete or marked just one or two options out of five throughout the questionnaire. So, quantitative data is based on 191 responses. Semi-structured interview protocol has been used to generate qualitative data from 15 students (five M.phil and 10 Master level) of the same units. Both types of data were taken only from those students who were willing to participate in the study. Descriptive statistics (frequency and percentage) has been used to analyse quantitative data, whereas content analysis has been used to analyse qualitative data.

\section{Data Presentation, Findings and Discussion}

The quantitative data has been presented followed by qualitative data. This will help to understand whether findings from qualitative data support quantitative results or not. Discussion is provided at the end of every subsection, and it is based on the findings of previous studies and researchers' personal observations/views/experience because the researchers' are from the same societal/organizational culture and have rich insider view. For the purpose ofdata analysis, responses under 'strongly agree and agree' are combined, and similarly responses under 'strongly disagree and disagree' are combined. The reason behind combining these responses is that these is no substantial difference between responses obtained against 'strongly agree and agree', and 'strongly disagree and disagree'. Following contractions/symbol have been used in the tables: Strongly Agree (SA), Agree (A), Disagree (D), Strongly Disagree (DA), Frequency (F) and Percentage (\%). 
Table -1

Literate parents

\begin{tabular}{|c|c|c|c|c|}
\hline \multirow[t]{2}{*}{ Questionnaire Items } & SA & $\mathbf{A}$ & D & SD \\
\hline & F (\%) & F (\%) & F (\%) & F (\%) \\
\hline $\begin{array}{l}\text { Literate parents wish their girls to be highly educated and } \\
\text { contribute in family/country's economy }\end{array}$ & $\begin{array}{c}50 \\
(26.2 \%)\end{array}$ & $\begin{array}{c}72 \\
(37.7 \%)\end{array}$ & $\begin{array}{c}47 \\
(24.6 \%)\end{array}$ & $\begin{array}{c}22 \\
(11.5 \%)\end{array}$ \\
\hline $\begin{array}{l}\text { Literate parents want their daughters to get higher } \\
\text { education to find good matches }\end{array}$ & $\begin{array}{c}61 \\
(31.9 \%)\end{array}$ & $\begin{array}{c}58 \\
(30.4 \%)\end{array}$ & $\begin{array}{c}47 \\
(24.6 \%)\end{array}$ & $\begin{array}{c}25 \\
(13.1 \%)\end{array}$ \\
\hline $\begin{array}{l}\text { Literate parents want to empower their daughters and } \\
\text { make them independent through higher education }\end{array}$ & $\begin{array}{c}57 \\
(29.8 \%)\end{array}$ & $\begin{array}{c}67 \\
(35.1 \%)\end{array}$ & $\begin{array}{c}51 \\
(26.7 \%)\end{array}$ & $\begin{array}{c}16 \\
(8.4 \%)\end{array}$ \\
\hline $\begin{array}{l}\text { Literate parents equip their daughters with higher } \\
\text { education to make them able to protect themselves } \\
\text { from exploitation }\end{array}$ & $\begin{array}{c}42 \\
(22 \%)\end{array}$ & $\begin{array}{c}71 \\
(37.2 \%)\end{array}$ & $\begin{array}{c}47 \\
(24.6 \%)\end{array}$ & $\begin{array}{c}31 \\
(16.2 \%)\end{array}$ \\
\hline
\end{tabular}

Data of first item in table 1 show that $63.9 \%$ (when strongly agree and agree are combined) of the respondents point out that literate parents wish their girls to be highly educated and contribute in family/country's economy. Whereas, 36.1\% (when strongly disagree and disagree are combined) participants contradict it. In response to statement no $2,62.3 \%$ of the respondents highlight that literate parents want their daughters to get higher education to find good matches. On the other hand, 37.7\% respondents opposed this opinion. On $3^{\text {rd }}$ statement, $64.9 \%$ believe that literate parents want to empower their daughters and make them independent through higher education. However, 35.1\% respondents reject this point of view. In response to $4^{\text {th }}$ item, 59.2\%respondentsbelieve that literate parents get their girls highly educated to enable them to protect themselves from exploitation; whereas $40.8 \%$ of the students reject this position. Qualitative data support these findings, as is evident from below response of one of the participants:

$G$ [sic-yes] educated parents never discriminate boys and girls while educating their children. Educated parents do not have focus on daughters' marriage only like uneducated parents. ...educated parents think if their girl is...[equipped] with higher education she can find good match and can deal with any problem such as financial problem after marriage because she can get job, in this way she can support the family financially. (Respondent(R), 9)

Another respondent added:

My father said me that you are like [my] ...son and through university education you should make yourself independent and powerful, like your brother. (R11)

An M.Phil student said:

My parents are highly qualified and both do job. They discuss at home [that] if girls are qualified in professional education...in-laws and society cannot misuse because they know [their] rights and can go court. (RI) 
Findings from table I and above presented qualitative data coincide the findings from previous studies. Stephan (2002) point out that females' higher education contributes in country's economic growth, this supports the present study finding that females with higher education can support family economically through doing job and it will also contribute to the country's economy. This study reveals that highly educated girls get more appropriate matches, Afghani (2015) supports this finding. This study further highlights that females' higher education enables them to be independent, empowered and save themselves from exploitation, previous studies support these findings (Sharma \& sharma, 2004; Sperling, 2004).

Table - 2

Global trend of females' higher education

\begin{tabular}{|c|c|c|c|c|}
\hline \multirow[t]{2}{*}{ Questionnaire Items } & SA & $\mathbf{A}$ & D & SD \\
\hline & F (\%) & F (\%) & F (\%) & F (\%) \\
\hline $\begin{array}{l}\text { International trend to equip girls with higher } \\
\text { education is helpful in females' progression in } \\
\text { higher education. }\end{array}$ & $\begin{array}{c}59 \\
(30.9 \%)\end{array}$ & $\begin{array}{c}80 \\
(41.9 \%)\end{array}$ & $\begin{array}{c}37 \\
(19.4 \%)\end{array}$ & $\begin{array}{c}15 \\
(7.9 \%)\end{array}$ \\
\hline $\begin{array}{l}\text { Parents in Pakistan are focusing on girls' } \\
\text { professional education to get job in line with } \\
\text { global trend. }\end{array}$ & $\begin{array}{c}69 \\
(36.1 \%)\end{array}$ & $\begin{array}{c}61 \\
(31.9 \%)\end{array}$ & $\begin{array}{c}43 \\
(22.5 \%)\end{array}$ & $\begin{array}{c}18 \\
(9.4 \%)\end{array}$ \\
\hline $\begin{array}{l}\text { Parents are comfortable to send their daughters in } \\
\text { universities in big cities. }\end{array}$ & $\begin{array}{c}52 \\
(27.2 \%) \\
\end{array}$ & $\begin{array}{c}74 \\
(38.7 \%) \\
\end{array}$ & $\begin{array}{c}46 \\
(24.1 \%) \\
\end{array}$ & $\begin{array}{c}19 \\
(9.9 \%) \\
\end{array}$ \\
\hline $\begin{array}{l}\text { For higher education parents do not feel } \\
\text { hesitation to allow their girls to live in hostels. }\end{array}$ & $\begin{array}{c}49 \\
(25.7 \%)\end{array}$ & $\begin{array}{c}71 \\
(37.2 \%)\end{array}$ & $\begin{array}{c}40 \\
(20.9 \%)\end{array}$ & $\begin{array}{c}31 \\
(16.2 \%)\end{array}$ \\
\hline $\begin{array}{l}\text { Parents have no demand of females' only } \\
\text { institutions and they permit their girls to join co- } \\
\text { education universities. }\end{array}$ & $\begin{array}{c}44 \\
(23 \%)\end{array}$ & $\begin{array}{c}76 \\
(39.8 \%)\end{array}$ & $\begin{array}{c}53 \\
(27.7 \%)\end{array}$ & $\begin{array}{c}18 \\
(9.4 \%)\end{array}$ \\
\hline $\begin{array}{l}\text { Establishment of public and private universities } \\
\text { in some backward areas reduced the families' } \\
\text { concern regarding their girls' mobility to big } \\
\text { cities for higher education. }\end{array}$ & $\begin{array}{c}61 \\
(31.9 \%)\end{array}$ & $\begin{array}{c}64 \\
(33.5 \%)\end{array}$ & $\begin{array}{c}46 \\
(24.1 \%)\end{array}$ & $\begin{array}{c}20 \\
(10.5 \%)\end{array}$ \\
\hline
\end{tabular}

Data on item 1 show that $72.8 \%$ (when strongly agree and agree are combined) students highlight that international trend to equip girls with higher education is helpful in females' progression in higher education. Whereas, $27.3 \%$ (when strongly disagree and disagree are combined) respondents contradict this point of view. In response to $2^{\text {nd }}$ item, $68 \%$ respondents think that parents in Pakistan are focusing on girls' professional education to get job in line with global trend. However, $31.9 \%$ participants oppose it. For $3^{\text {rd }}$ item, $65.9 \%$ participant have the point of view that parents are comfortable to send their daughters in universities in big cities. On the other hand, 34\% participants disagree with this position. On $4^{\text {th }}$ statement, $62.9 \%$ students highlight that for higher education parents do not feel hesitation to allow their girls to live in hostels. Whereas, $37.1 \%$ students 
negate this view. In response to item 5, 62.8\% respondents think that parents have no demand of females' only institutions and they permit their girls to join co-education universities. However, 37.1\% respondents disagree with it. On $6^{\text {th }}$ statement, 65.4\% participants highlight that establishment of public and private universities in some backward areas reduced the families' concern regarding their girls' mobility to big cities for higher education. On the other hand 34.6\% participants oppose it. These findings from quantitative data are supported by the qualitative data that is evidenced from a respondent's comment:

I think there is international trend that now more girls are getting higher education as compared to past. This international trend also present [sic-exist] in Pakistan. Many parents when see [that] others' daughters are obtaining professional degrees and in turn [sic-based on those degrees] doing jobs, they become motivated to send their daughters to do professional degrees. Therefore I think this international trend is helpful in the progression of girls' higher education. (R4)

Another student said:

$G$ [sic-yes] I think so...for example look at me [sic-look at my example] I am from a poor [sic-backward] village of D.G. Khan [a district of South Punjab, Pakistan] but my father supported me to get admission in this university in Lahore because he says Lahore is big city and you learn more in big city because of competition. ...he already knows that this is a co-education university and I will live in hostel, but he gave me confidence. (R7)

Two more participants added:

Yes, in my opinion global trend of girls' professional or higher education is very supportive factor that is creating awareness in [sic-among] parents in Pakistan about the importance of girls' higher education... In my opinion because of this reason many parents are sending their daughters in big cities for professional and higher education degrees...in my M.Phil class about half female students are from villages. (R10) ...I would say yes...because when girls and [their] parents see highly educated women are doing jobs in offices...in hospitals as doctor and are anchor persons at T.V. they get inspiration...my neighbour in my village who was senior than me in school is selected as justice...complete [sic-whole] village is proud of her. (R13)

Data of table 2 and qualitative data presented above indicate that global trend of females' higher education is getting common in Pakistan and around the world. This is supported by recent studies (Kaleem \& Rathore, 2017; Bilton, 2018). Females with higher education are joining the professional fields as well. This phenomenon can be observed through looking at employees' data of public and private sector. As a result of this, 
monetary power is shifting from males only to females to some extent, which in turn is making them empowered and lessening their reliance on men. Because of benefits attached to the girls' higher education parents now do not demand for female specific institutions, rather they are allowing their daughters to go to big cities and live in hostels. The education and awareness from media enabled parents to think broadly. Parents now have acknowledged the fact that country like Pakistan cannot afford gender specific institutions. More importantly if females will study with males, it will create a sense of competition among them and it will also be helpful to reduce the culture of male dominancy in society.

Table -3

Women's development

\begin{tabular}{|c|c|c|c|c|}
\hline \multirow[t]{2}{*}{ Questionnaire Items } & SA & A & D & SD \\
\hline & F (\%) & F (\%) & F (\%) & F (\%) \\
\hline $\begin{array}{l}\text { Media create awareness among parents } \\
\text { regarding girls' higher education } \\
\text { through different programmes }\end{array}$ & $\begin{array}{c}53 \\
(27.7 \%)\end{array}$ & $\begin{array}{c}85 \\
(44.5 \%)\end{array}$ & $\begin{array}{c}37 \\
(19.4 \%)\end{array}$ & $\begin{array}{c}16 \\
(8.4 \%)\end{array}$ \\
\hline $\begin{array}{l}\text { Special quota for females in jobs } \\
\text { motivated the girls and their parents to } \\
\text { get higher education }\end{array}$ & $\begin{array}{c}56 \\
(29.3 \%)\end{array}$ & $\begin{array}{c}66 \\
(34.6 \%)\end{array}$ & $\begin{array}{c}35 \\
(18.3 \%)\end{array}$ & $\begin{array}{c}34 \\
(17.8 \%)\end{array}$ \\
\hline $\begin{array}{l}\text { Local and foreign scholarships } \\
\text { encouraged girls for higher education }\end{array}$ & $\begin{array}{c}59 \\
(30.9 \%) \\
\end{array}$ & $\begin{array}{c}72 \\
(37.7 \%) \\
\end{array}$ & $\begin{array}{c}49 \\
(25.7 \%) \\
\end{array}$ & $\begin{array}{c}11 \\
(5.8 \%)\end{array}$ \\
\hline
\end{tabular}

Table 3 shows that in response to item 1,72.2\% (when strongly agree and agree are combined) of the participant highlight that media create awareness among parents regarding girls' higher education through different programmes. Whereas, $27.8 \%$ (when strongly disagree and disagree are combined) participants contradict with it. On item 2, $63.9 \%$ students believe that special quota for females in jobs motivated the girls and their parents to get higher education. However, 36.1\% students disagree with this point. In reply to $3^{\text {rd }}$ statement, $68.6 \%$ respondents point out that local and foreign scholarships encouraged girls for higher education. While, $31.5 \%$ participants reject this point of view. Qualitative support of these findings is presented below:

Yes...both print and electronic media is playing very supportive role in making world [society] aware about the importance of girls' higher education. Government and non-government organizations run their campaign regarding girls education through media... and when women working on top positions tell their success stories on T.V. it also attract the society and girls to get higher education. (R12)

Another student shared her experience:

I am getting reasonable amount from HEC [Higher Education Commission] and I won this scholarship totally on merit...I will also apply for Ph.D scholarships 
after M.Phil. (R15)I want to support my family...I am sure I can get good job because I have very good CGPA in my M.Phil and government allocated quota for females...recently my elder sister is also appointed as school teacher near home. (R3)

Results from table 3 and qualitative data point out that government initiatives such as foreign and local scholarships for girls' school/higher education, and then quota in government jobs for females is a significant factor for females' progression in higher education and women's development. All the researchers of this paper got their terminal degrees from England through HEC scholarship and then doing current job based on that qualification. Being female co-author of this paper I would like to share that higher education and my job made me empowered and independent, which is in support of the findings of this study. Being Pakistani researchers we have also observation that media especially electronic media played a critical role to motivate society for girls' higher education. Because of these factors rate of working women is increasing in Pakistan. Working women manage their professional life and home better than men (Heise, Ellsberg \& Gottemoeller, 1999). However it is interesting to know that two-third work of the worlds is done by women, but their earning is one-tenth of the world's total earning and they have just one-hundredth of the world's total assets (Suresha \& Mylarappa, 2012:361).

Table - 4

Islamic perspective

\begin{tabular}{|c|c|c|c|c|}
\hline \multirow[t]{2}{*}{ Questionnaire Item } & SA & $\mathbf{A}$ & D & SD \\
\hline & F (\%) & F (\%) & F (\%) & F (\%) \\
\hline $\begin{array}{l}\text { Islam never prohibit females from } \\
\text { getting any level of education rather } \\
\text { Islam makes obligation of females to } \\
\text { get education. }\end{array}$ & $\begin{array}{c}44 \\
(23 \%)\end{array}$ & $\begin{array}{c}74 \\
(38.7 \%)\end{array}$ & $\begin{array}{c}54 \\
(28.3 \%)\end{array}$ & $\begin{array}{c}19 \\
(9.9 \%)\end{array}$ \\
\hline
\end{tabular}

Table 4 show that $61.7 \%$ (when strongly agree and agree are combined) students point out that Islam never prohibit females from getting any level of education rather Islam makes obligation of females to get education. Whereas, $38.2 \%$ (when strongly disagree and disagree are combined) students disagree with this. A participant remarked that:

Definitely yes...Hazrat Muhammad (PBUH) said, "Seeking knowledge is a duty of every Muslim [male and female]". There is no discrimination of male and female when Islam emphasizes and makes obligation of Muslims to get education. Since I am a Muslim, therefore I believe that Islam supports the females' higher education. (R8) 
Another M.Phil student endorsed that:

Yes, no doubt Islam says all male and female Muslims to get education...I am going to complete my M.Phil degree I didn't read anywhere that Islam prohibits females from getting education. This is very bad [sic-illogical]... usually uneducated or less educated people misinterpret Islam. (R2)

Various researchers support the above stated finding from quantitative and qualitative data that Islam equally emphasises the education of both male and female (Onaid, 2014; Armstrong, 2006). We researchers, being a Muslim, have the same belief that Islam makes the knowledge seeking mandatory for every Muslim male and female, and in Islam there is no discrimination based on gender regarding knowledge acquisition.

\section{Conclusions and Implications}

It is concluded that literate parents are very supportive and want their daughters to get higher education to be independent/empowered, secure from various kinds of discrimination/exploitation, contribute in family/country's economic growth, and find better matches for them. These findings are appealing and logical in a sense that when there are highly educated girls, professional men would like to marry with such girls instead uneducated. There is reason behind this thought that educated mother grooms and educates their children that makes the whole family educated. Highly educated mother wants her daughter to be empowered through higher education. When females are highly educated they are less likely to be discriminated/exploited because they are aware with their rights and can go to court to get these in case (Ahmad, 2001 \& 2006). Higher education enables females to get job that makes them less reliant on men along with contribution to the family and country's economy. However, it is important to note that out of $42 \%$ illiterate people of Pakistan majority are parents. So, there is need to run campaign to educate these parent about the importance of girls' school/higher education.

Moreover, global trend of equipping females with higher education is another important factor that is playing positive role in females' progression in higher education, and parents are now sending their daughters in co-education universities of big cities. Fastpaced changes occurring in all aspects of life in every moment anywhere in the world influence the whole global community because world is now global village. So, benefits attached to girls' higher education are now more visible. When people from developing and underdeveloped countries look at the attractive life of highly educated women especially from developed countries through internet and social/electronic/print media, they get inspire to send their daughters for higher education. When people see that overall in the world girls' education is becoming priority, this motivates parents for the same. Highly educated girl is more likely to find good match even from abroad or can settle there because of her qualification. Therefore, parents now have no demand of females 
only institution and they are sending their daughters to big cities allowing them to live in hostels to make them able to live in a competitive era of globalization. However, access to media and awareness of the significance of girls' higher education do not exist as such in most of the rural areas of Pakistan. So, there is need to provide this access and educate parents regarding the importance of girls' education in general and their higher education specifically.

Another conclusion is that discussion regarding the importance of females' higher education on every kind of media, scholarships for females' education and quota for females in jobs are found as encouraging factors for females' progression in higher education. As mentioned in the introductory part women are around half of the world's population but their contribution in the world's economy is too low. World as a global village cannot progress at desired pace until females' contribute in economy after getting higher education. So, role of Women Development Departments and other government and non-government agencies to educate, empower and involve women in employment and entrepreneurship is critical for the overall global development. These agencies should expand their role and scope to cover all area of Pakistan in this regard.

Finally, it is concluded that Islam never restricts females from getting higher education and doing job. It is important to educate people through rigorous campaign that true spirit of Islam do not prohibits females from getting education, instead Islam makes it binding for every Muslim male and female to seek knowledge.

\section{References}

Afghani, A. (2015). Problems and Prospects of Females' Education: A Case of a Public University of Punjab, Pakistan. Unpublished M.Phil Thesis, University of Education, Lahore.

Aftab, T. (1995). Challenge for Change: Literacy for the Girl of Today, the Woman of Tomorrow. Centre of Excellence for Women, University of Karachi.

Ahmad, F. (2001). Modern Traditions? British Muslim Women and Academic Achievement, Gender and Education, vol.13:2, pp.137-152.

Ahmad, F. (2006). Modern Traditions?: British Muslim Women, Higher Education and Identities. Unpublished Thesis, University of Bristol.

Al-Sunan, 1:81-224. 
104 What Supports Females in Higher Education Progression? A Pakistani Public University Context

Ali, R., Jumani, N.B. \& Ejaz, S. (2015). Higher Education of Women in Pakistan: Promises, Achievements and Barriers. Pakistan Journal of Women's Studies: Alam-e-Niswan, vol.22:2, pp.59-75.

Amin, M., Tatlah, I.A. \& Afghani, A. (2018). Problems of Females' Progression in Higher Education: Perceptions of Female University Students. Pakistan Journal of Gender Studies, vol.16:1, pp.71-88.

Armstrong, K. (2006). Muhammad: A Prophet for Our Time. Harper Collins.

Banuri, T. (2019). HEC Chairman Dubs Higher Education Budget, 'Peanuts'. Retrieved on $16^{\text {th }}$ June from https://academiamag.com/higher-education-budget/.

Bilton, I. (2018). Women are Outnumbering Men at a Record High in Universities Worldwide. Retrieved on $21^{\text {st }}$ June from https://www.studyinternational.com/ news/record-high-numbers-women-outnumbering-men-university-globally/.

Colclough, C., Rose, P. \&Tembon, M. (2000). Gender Inequalities in Primary Schooling: The Roles of Poverty and Adverse Cultural Practice. International Journal of Educational Development, vol.20, pp.5-27.

David, M. (1993). Parents, Gender \& Education Reform. Polity Press. Oxford, UK.

Francis, B. \& Skelton, C. (2001). Investigating Gender. Contemporary Perspectives in Education, vol.3:1, pp.2-6.

Government of Pakistan (2003). Report of the Pakistan Commission on the Status of Women. Women Division: Islamabad.

Heise, L., Ellsberg, M. \&Gottemoeller, M. (1999). Ending Violence against Women: Population Reports. 27(4). Population Information Program Centre for Communication Programs, The Johns Hopkins University.

Huda (2019). Education for Girls in Islam. Retrieved on $22^{\text {nd }}$ June from https://www.learnreligions.com/girls-education-in-islam-2004260.

Kaleem, R. \&Rathore, K. (2017). Trends of Higher Education among Female Students: The Case of University of the Punjab. Governance and Management Review, vol.2:1, pp.19-44. 
Khattak, S.G. (2009). Gender Issues in Higher Education in Pakistan. Studies in the Humanities, vol.36:2, pp.102-.

Literacy Rate has Fallen to 58pc, Minister tells Senate. (2018, December 18). Dawn. Retrieved on $21^{\text {st }}$ July from https://www.dawn.com/news/1452740.

Maqsood, F., Maqsood, S. \& Raza, H. (2012). Getting Higher Education: Is it Really a Challenge for Females in Pakistan? Academic Research International, vol.2:3, pp.352-360.

Mehmood, S., Chong, L. \& Hussain, M. (2018). Females Higher Educationin Pakistan: An Analysis of Socio-Economic and Cultural Challenges. Advances in Social Sciences Research Journal, vol.5:6, pp.379-397.

MFEPT (2017). National Education Policy 2017-2025. Islamabad: Ministry of Federal Education and Professional Training, Government of Pakistan.

Naeem, T. \& Dahar, M.A. (2016). Investigation of Problems Faced by Female Students at Higher Education Level. Sci.Int.(Lahore), vol.28:2, pp.1997-2000.

Onaid, F. (2014). The Importance of Girls' Education in Islam. Retrieved on $22^{\text {nd }}$ June from https://www.whyislam.org/social-ties-2/the-importance-of-girls-education-in-islam/.

Osunde, A.U. \&Omoruyi, F.E.O. (2003). An Assessment of Women Attitude towards Special Skills Training Programs in Nigeria. Implications for Programmes Development and Implementation, Convergence, vol.30:4, pp.93-102.

Quran, Chapter 39, Verse 9.

Quran, Chapter 96, Verse 1-5.

Richardson, H. (2016). Why do More Women than Men go to University? Retrieved on $21^{\text {st }}$ June from https://www.bbc.com/news/education-37107208.

Sharma, U. \& Sharma, M.B. (2004). Women and Higher Education. Common Wealth Publishers. New Delhi, India.

Shaukat, S. \& William Pell, A. (2015). Personal and Social Problems Faced by Women in Higher Education. FWU Journal of Social Sciences, vol.9:2, pp.101-109. 
Sperling, G. (2004). What Works in Girl Education: Evidence and Policies from the Developing World. Speaking at the Council on Foreign Relations. file:///C:/Users/Admin/Downloads/Girls_Education_full.pdf

Stephan, K. (2002). Does Gender Inequality Reduce Growth and Development? Evidences from Cross-Country Regressions. World Bank Policy Research Report Working Paper Series No. 7.

UNESCO (2008). Medium Term Strategy, 2008-2013. UNESCO. Paris, France

UNESCO (2012). World Atlas of Gender Equality in Education, Retrieved on $22^{\text {nd }}$ July from https://www.macfound.org/media/files/UNESCO-world-atlas-gender-education.pdf.

UNESCO (2019). Pakistan's Literacy Rate. UNESCO Institute of Statistics. Retrieved on $15^{\text {th }}$ June from http://uis.unesco.org/country/PK.

Women Development Department (2019). Who We Are? Women Development Department: Government of the Punjab. Retrieved on $20^{\text {th }}$ July from https://wdd.punjab.gov.pk/.

Dr. M. Amin is an Assistant Professor in the Department of Education, University of Education, Lahore, Multan Campus.

Dr. Muhammad Islam is an Assistant Professor in the Department of Education IER, University of Punjab, Lahore, Pakistan.

Ms. Humera Amin is Lecturer in the Department of Education, University of Education, Lahore, Multan Campus. 